\title{
A MOBILIDADE URBANA NA URBANIZAÇÃO DAS FAVELAS NO RIO DE JANEIRO
}

\author{
Fabiana Izaga \\ Margareth da Silva Pereira*
}

\begin{abstract}
RESUMO
O crescimento urbano no Rio de Janeiro tem na favela um de seus aspectos mais marcantes do ponto de vista da conformação da paisagem, ao que se somam valores espaciais, culturais e econômicos. Neste artigo buscaremos desenvolver uma compreensão ampla da política habitacional no Rio de Janeiro, investigando como a questão da mobilidade urbana vem sendo enfrentada através dos dois últimos programas implementados de urbanização de favelas, o Favela-Bairro (1993) e o mais recente Programa de Aceleração ao Crescimento - PAC (2007). Mais especificamente serão enfocadas a Favela da Rocinha, o Complexo PavãoPavãozinho/Cantagalo e o Complexo do Alemão. Buscaremos compreender como em cada uma destas favelas, que receberam investimentos recentes para urbanização através do PAC, desenvolve-se o tema da mobilidade urbana.
\end{abstract}

Palavras-chave: mobilidade urbana; habitação; favela; Rio de Janeiro

\begin{abstract}
Rio de Janeiro's urban growth has in the favelas outstanding aspects that shape the landscape; to which are added spatial, cultural and economic values. In this article we pursue a wide comprehension of Rio de Janeiro's housing policies, investigating how urban mobility has been approached through the last two implemented programs, the Favela-Bairro (1993), and more recently, the Growth Acceleration Program - PAC (2007). Specifically we'll focus on the Favela da Rocinha, Pavão-Pavãozinho/Cantagalo Complex, and the Alemão Complex. We'll look foward to understanding how each one of this favelas, that received investments from PAC, dealt with urban mobility issues.
\end{abstract}

Keywords: urban mobility; housing; favela; Rio de Janeiro

\footnotetext{
* Fabiana Izaga: Profa. Dra. da Faculdade de Arquitetura e Urbanismo FAU, Universidade Federal do Rio de Janeiro - UFRJ. Pesquisadora ProUrb FAU-UFRJ. fabizaga@gmail.com

Margareth da Silva Pereira: Profa. Dra. da Faculdade de Arquitetura e Urbanismo FAU, Universidade Federal do Rio de Janeiro - UFRJ. Coordenadora ProUrb FAU-UFRJ. margaspereira@gmail.com
} 


\section{Introdução}

Dados recentes (IBGE, 2010) indicam a presença de aproximadamente 425 mil domicílios em 763 aglomerados chamados "subnormais" (onde se incluem as favelas, loteamentos irregulares e assentamentos sem infraestrutura ou propriedade da terra) no Rio de Janeiro. Os números indicam que em torno de 1,5 milhões de pessoas habitam em áreas informais na cidade, ou aproximadamente $25 \%$ do total da população carioca. O primeiro recenseamento de favelas, de 1948, apontava a existência de aproximadamente 35 mil domicílios, 138 mil habitantes, ou $7 \%$ da população total. Este expressivo aumento reflete a tortuosa trajetória da população pobre em relação à oferta de moradia.

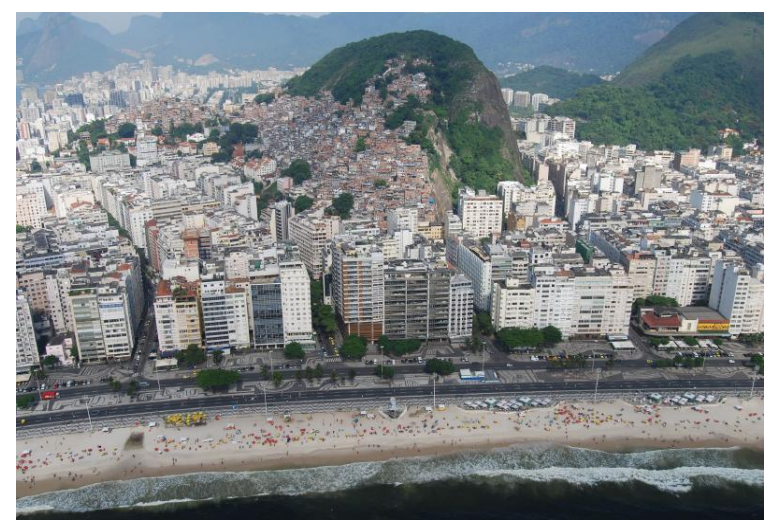

Foto 1 - Favela Pavão-Pavãozinho/Cantagalo, Rio de Janeiro. Fonte: Grupo de Pesquisa Quapá-Sel, USP, 2008.

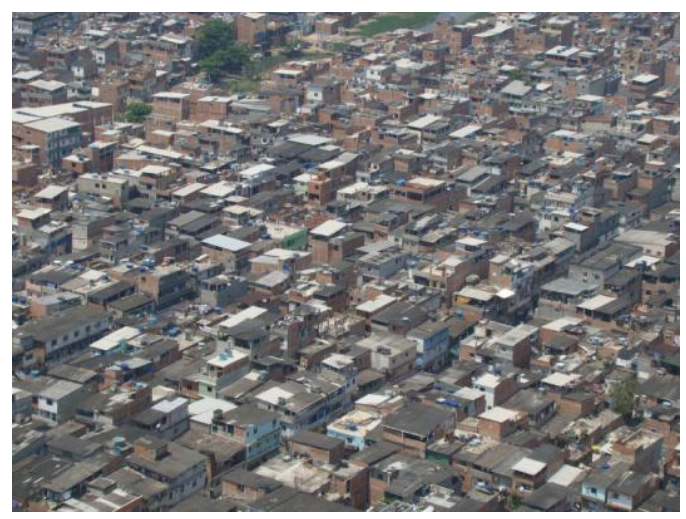

Foto 2 - Favela Detalhe, Rio de Janeiro. Fonte: Grupo de Pesquisa Quapá-Sel, USP, 2008.

Desde o final do século XIX, com o crescimento demográfico alimentado pelo movimento de imigração e com os deslocamentos internos de população, as camadas mais pobres, sem opção de moradia, passaram a se aglomerar em locais sem infraestrutura para habitação, como encostas de morros ou à beira de rios. Por outro lado, essa tendência passou também a ser acentuada por uma política urbanística de intervenções que se propunha mudar a face do velho Rio colonial, de becos estreitos e velhos casarões, para dar lugar a avenidas largas, ventiladas, salubres e, sobretudo, modernas, expulsando a população, até então, aí residente. Pode-se dizer que assim surgiram as primeiras favelas cariocas, movimento que continuou sendo agravado já no século XX pelo caráter sistemático e abrangente destas políticas de renovação e reconfiguração arquitetônica e urbanística da área central da cidade e que geraria enormes repercussões sociais e um cenário de crise habitacional. 
Parte da população desalojada deslocou-se para os subúrbios, estruturados a partir dos ramais ferroviários, e que, embora distantes, ofereciam a possibilidade de moradias a valores acessíveis. Entretanto, para a grande maioria dessa população a mudança para o subúrbio era uma saída inviável, visto que não podiam arcar com as consequentes despesas de moradia e transportes. É desta forma, e sob um olhar complacente das autoridades, que alguns morros, sobretudo no entorno imediato do antigo centro, passaram a ser rapidamente ocupados, dando origem às primeiras favelas como Providência, São Carlos e Santo Antônio.

Figura 1. Mapa das Favelas do Rio de Janeiro, 2008.

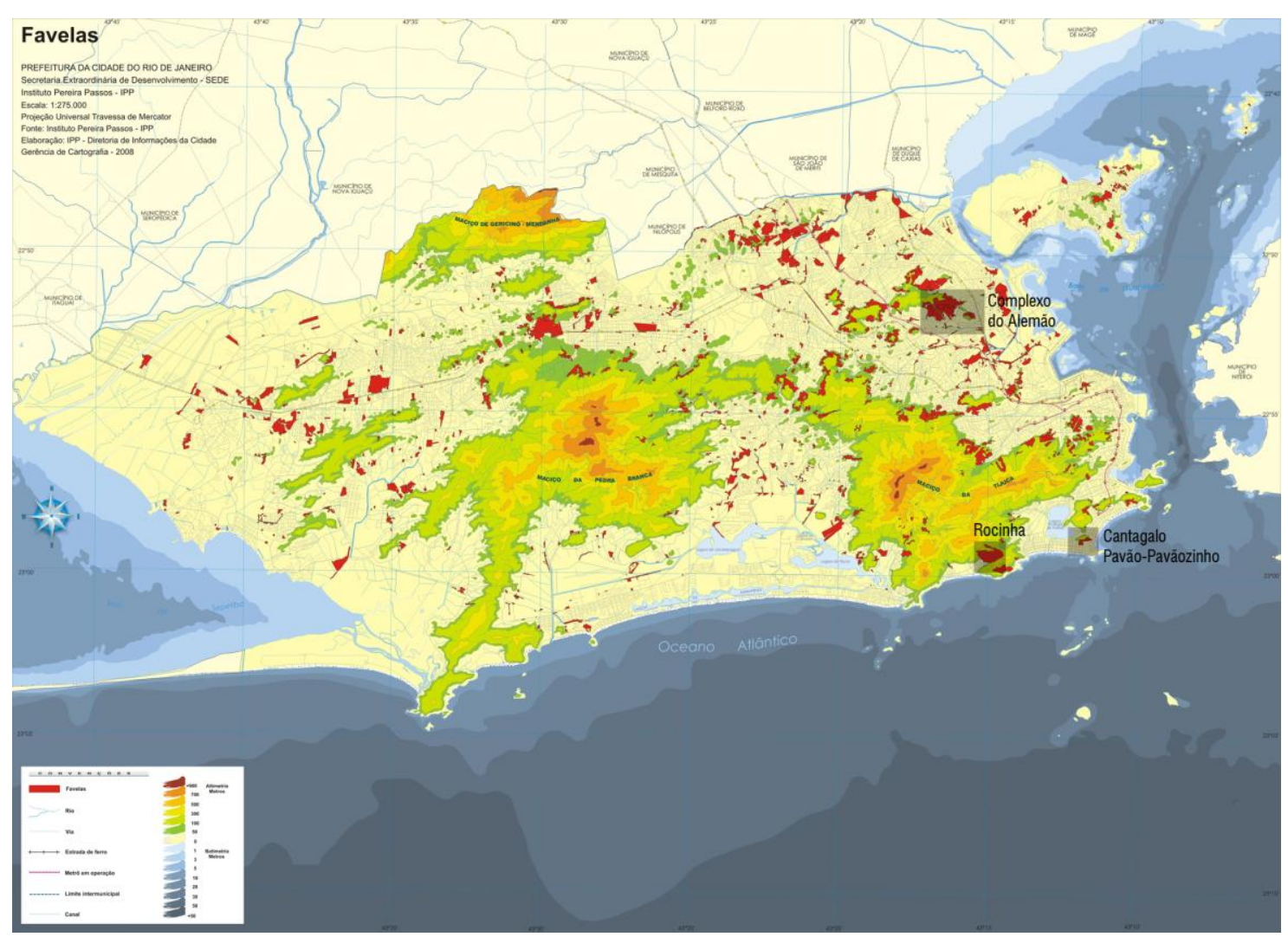

Fonte: IPP-Rio, PCRJ (Instituto Pereira Passos-Rio de Janeiro, Prefeitura da Cidade do Rio de Janeiro).

A favela como questão urbana atravessaria o século $\mathrm{XX}$ através de quatro visões distintas (Valladares, 2006). Uma primeira de constituição de um mito, de origem literária, pela qual a visão do escritor Euclides da Cunha a apresenta ligada a uma dualidade litoral $\mathrm{x}$ sertão e cidade x favela. Desse período de descoberta, passa-se, em um segundo momento, a uma percepção da favela como problema social e urbanístico - que embora fisicamente visível seria negligenciado. O melhor retrato dessa situação reflete-se no Decreto 6000 do “Código de Obras do Distrito Federal" (1937) que proibia o registro de favelas no mapa oficial da cidade, assim como a construção de novas moradias ou melhorias nesses locais. 
Um terceiro momento identifica-se com o tratamento administrativo do problema através de medidas e de políticas concretas. Destaca-se, neste sentido, a política de remoção das favelas com a consequente mudança de suas populações para Parques Proletários Provisórios, localizados em locais distantes em relação ao núcleo central urbanizado, onde a substituição de casas transitórias pelas definitivas jamais ocorreria. O quarto momento se impõe através do necessário reconhecimento da existência da favela e pela produção de dados oficiais, cujo marco é o Recenseamento de Favelas do Distrito Federal (Rio de Janeiro), de 1948, e o Recenseamento Demográfico de 1950 que identifica esse tipo de aglomerado urbano.

A partir da década de 1960 se observaria um quadro de forças atuante sob forte tensão, que oscila entre diretrizes opostas. Desta forma, se investiria simultaneamente na remoção da favela e na construção de conjuntos habitacionais em lugares distantes do local de trabalho e mal atendidos pelos transportes urbanos e demais serviços públicos. As remoções gerariam uma enorme resistência da população favelada que forma, em 1963, uma entidade federativa - a Federação das Associações de Favelas do Estado da Guanabara. O ápice da política de remoção de favelas ocorreu entre 1968 e 1975, quando cerca de 30\% da população favelada (em torno de 175 mil pessoas) foi levada para conjuntos habitacionais nas periferias. $\mathrm{O}$ programa de erradicação de favelas foi suspenso em 1974, sem que fosse adotada, imediatamente, para substituí-la, uma nova e consistente política.

Em 1979, com a criação de uma Secretaria de Desenvolvimento Social, se estabeleceu um marco importante com a formação do Programa de Educação Sanitária e do Projeto Mutirão, que forneciam material e prestavam assistência técnica e social para a autoconstrução de moradias. Com a democratização e o estabelecimento de uma Nova Constituição Brasileira, em 1988, se seguiu o Plano Diretor da Cidade do Rio de Janeiro, de 1992, instrumento que fixou parâmetros para a atuação do poder público no que se refere ao desenvolvimento e à expansão urbana, entre elas a urbanização das favelas e o processo participativo da população. Este é o primeiro documento oficial onde se percebe uma nova mudança de enfoque para o tema favela, abrindo campo para uma real integração com o restante da cidade, dentro dos mesmos padrões. Neste sentido, a favela é percebida como um território que integra a totalidade da cidade, e que a população que ali habita não deve ser afastada do centro urbano - com base, inclusive, em percepções sociais que insistem em sua periculosidade - como antes era alegado.

De fato, a análise do cenário das forças políticas que se entrecruzavam no início da década de 1990 remete à questão da violência, agora associada cada vez mais às favelas. Essa 
percepção da favela ganha força na medida em que desde a década de 1980 uma nova prática aparece em cena no espaço das favelas: a do narcotráfico. O tráfico de entorpecentes e o crime organizado ganhariam espaço em meio aos vácuos de poder legítimo dentro das favelas, pois se apresentariam como alternativas de renda para a população carente.

Assim, de forma geral já a partir da década de 1980, a tematização dos "problemas urbanos" em todo o Brasil, e especificamente no Rio de Janeiro, passou a ser acompanhada por uma reflexão sobre a necessidade de um planejamento estratégico e se refletiu em certas ações políticas implementadas na década seguinte.

No nível municipal, por exemplo, em 1992 a Câmara Municipal do Rio de Janeiro já havia regulamentado, com esse entendimento, a organização dos Planos Diretores decenais da cidade, a partir de anteprojeto de lei encaminhado pelo então prefeito Marcelo Alencar. Com base nessas diretrizes, mas ao mesmo tempo se superpondo à aplicação do Plano Diretor aprovado na gestão precedente, o novo prefeito eleito, César Maia (1993-1996), pautará sua gestão por uma filosofia de "reconstrução" da cidade, contratando para tanto um "Plano Estratégico" pautado no modelo catalão. O lema da reconstrução, presente na formulação de seus principais projetos, de certo modo terá continuidade também no governo de Luiz Paulo Conde, seu secretário de Urbanismo à época e que lhe sucedeu imediatamente na Prefeitura (1996-2000).

No que diz respeito às favelas, desde 1992 vinha ganhando forma o Programa de Urbanização de Assentamentos Populares - com recursos do Banco Interamericano de Desenvolvimento (BID). Assim, em 1993, o novo prefeito criaria um grupo de trabalho para definir as bases da política habitacional para a cidade. São criados diversos programas voltados para atender diferentes situações de precarização da habitação como o Programa Favela-Bairro, dirigido para as favelas; o "Morar Legal", de regularização de loteamentos irregulares e o "Novas Alternativas", que trabalhou na recuperação de antigas vilas e cortiços, entre outros.

Em 1994 foi (re)criada a Secretaria Municipal de Habitação (SMH-RJ), órgão que existia na gestão da cidade desde 1946 mas que havia desaparecido na nova árvore administrativa, organizada quando o Rio deixou de ser o Distrito Federal, em 1960. Pode-se dizer que o enfrentamento de modo abrangente e simultâneo do problema da habitação para a população pobre se definiria como um divisor de águas na história da política habitacional carioca. 


\section{Favela-Bairro}

O Programa Favela-Bairro (1993) deve ser entendido como uma tentativa de dar respostas à crescente fragmentação do tecido urbano, no qual as favelas eram identificadas, sobretudo, como territórios segregados e desconectados. Esta compreensão era, e ainda o é, potencializada pelo seu reconhecimento como local de concentração do tráfico de drogas e da marginalidade, e pelo juízo, perpetuado pelo preconceito, de que o favelado pertenceria a uma outra esfera social.

O Programa Favela-Bairro constituiu, desta forma, em uma tentativa da Prefeitura de formular uma política integrada que desse conta da população que se encontrava em muitos aspectos à margem do acesso aos bens e equipamentos urbanos. Ao pensamento da favela como gueto urbanístico, marcado pela ausência de serviços públicos, o programa se propôs a integrá-las à cidade formal através da implantação de redes de infraestrutura, equipamentos urbanos e da oferta de serviços públicos. O Favela-Bairro foi formulado para as favelas de tamanho médio (entre 500 e 2.500 domicílios) com os objetivos de: "inserir as favelas na infraestrutura urbana"; "implantar as infraestruturas básicas"; "criar condições de melhoramento e integração social e ambiental".

\section{Figura 2. Programa Favela-Bairro. 600mil habitantes, 155 favelas contempladas.}

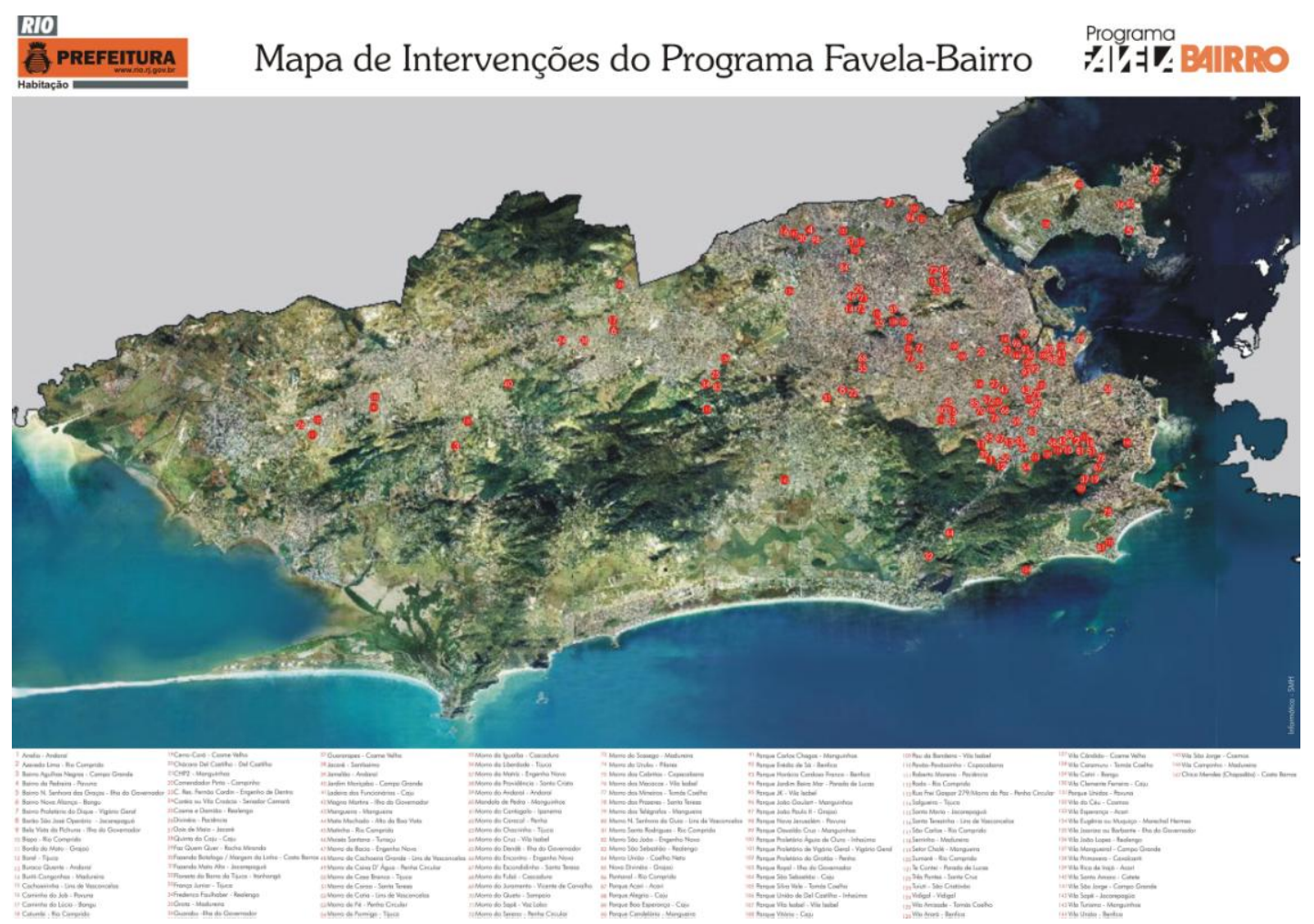

Fonte: Secretaria Municipal de Habitação, Prefeitura da Cidade do Rio de Janeiro, 1998. Disponível em: <http://www0.rio.rj.gov.br/habitacao/mapas.htm\#> 
A partir de um convênio firmado entre a Prefeitura do Rio de Janeiro e o BID, foi prevista uma verba de US\$ 300 milhões no âmbito do Programa de Urbanização de Assentamentos Populares do Rio de Janeiro (PROAP). O contrato estabelecia que o BID financiasse $60 \%$ desse montante, ficando o restante como contrapartida municipal. O PROAP continha três componentes: regularização de loteamentos; educação sanitária e ambiental; e urbanização de favelas, onde se inseriu o Programa Favela-Bairro, com a maior parte dos recursos: US\$192 milhões. No início de 2000, a Prefeitura e o BID assinaram um novo contrato, o PROAP2, de igual valor e teor do primeiro. Ao todo, ao que se somam outros recursos garantidos com outras instituições semelhantes, a Prefeitura atuou em mais de 150 comunidades faveladas, alcançando uma população de 550 mil pessoas, naquele momento aproximadamente mais da metade da população moradora em favelas no Rio do Janeiro (Conde e Magalhães, 2004:56).

Entre os vários aspectos urbanísticos do programa, a conexão viária entre a favela e o bairro do entorno e a acessibilidade intrafavela vão se constituir nas principais questões ligadas à mobilidade urbana. Do ponto de vista do direito à mobilidade no interior da própria favela, outros dois aspectos foram considerados dignos de nota: a prevalência das áreas privadas sobre as públicas e a ambiguidade dos espaços públicos que misturam diferentes usos: circulação, lazer e convívio.

Nas intervenções realizadas observou-se a intenção de melhorar as condições de acesso rodoviário ao interior da favela assim como foi dada atenção à circulação de pedestres visando ao atendimento das exigências de comodidade e ergonomia e à delimitação dos espaços públicos e privados.

A grande ênfase colocada sobre a oferta de serviços públicos para tornar a favela parte integrante da dinâmica da cidade formal levou ao alargamento de alguns trechos do tecido urbano informal existente, embora o programa não considerasse essas obras explicitamente sob o prisma da mobilidade. O fato é que as bordas das favelas, onde possível, passaram a ganhar novas conexões ou acessos mais francos.

O movimento inverso - qual seja o de pensar a favela a partir das suas centralidades, que estariam ligadas a outras centralidades urbanas, mais próximas ou mais distantes - não foi um aspecto considerado. Outro aspecto relevante deixado, contudo, de lado naquele momento foi a visão de uma favela como um local denso com ampla demanda de transporte, uma vez que em muito poucos casos o transporte urbano formal atende à sua população. 
Ora, data de meados da década de 1980 o início de serviços informais de transporte através da própria iniciativa dos moradores como uma resposta à ausência de políticas públicas para estas áreas, com uma demanda forte e negligenciada. Na década seguinte consolida-se o que se convencionou chamar de "cabritinhos" ou os serviços de kombis (Wolkswagen) e motos-táxi, que conseguem ter ainda mais penetração em vielas e ruas estreitas, como é característico da favela. Note-se, ainda, que as motos-táxi, ou serviço de transporte individual remunerado de passageiros em motocicletas, apesar de operarem em favelas desde aqueles anos, só foram incluídas no Código de Trânsito Brasileiro com a promulgação da Lei no 12.009 , em 2010.

Entretanto, mesmo nas favelas que receberam investimentos do PROAP I e II, a existência de traficantes e do crime organizado permaneceria como uma questão delicada, e o seu enfrentamento só passou a ser claramente objeto de políticas públicas a partir do momento em que a cidade do Rio de Janeiro foi eleita para sediar grandes eventos internacionais. Com o alinhamento das esferas políticas municipal, estadual e federal foi criado, por iniciativa do Governo do Estado, o conceito das Unidades de Policiamento Pacificadoras - UPPs. Estas passaram a adotar um novo modelo de segurança pública, no qual a polícia ocupa as "comunidades" e o policiamento busca promover a sua aproximação com a população local. A primeira UPP foi instalada no Morro Dona Marta em 19 de dezembro de 2008, sendo que no momento atual contabiliza-se a implantação de 37 UPPs em favelas (http://.upprj.com).

Com a maturidade do Favela-Bairro, absorvido na rotina da Secretaria Municipal de Habitação e sem iniciativas de atualização de suas premissas iniciais pela própria Prefeitura, a partir do segundo mandato do prefeito César Maia (2001-2005) o programa não mais apresentava o frescor dos primeiros anos. A própria dinâmica da favela, após a experiência dos primeiros anos de urbanização, se revelaria socialmente muito mais complexa. A clara imagem de toda uma população socialmente marginalizada, mas homogênea, nas favelas cedeu lugar à constatação de uma mistura social muito mais difusa formada por trabalhadores de camadas médias e também por universitários, associações culturais organizadas, entre outros.

A política urbana proposta através do Programa Favela-Bairro ganhou proporções muito mais amplas em relação às inicialmente previstas, tanto no que se refere ao volume de assentamentos envolvidos, quanto pela repercussão do reconhecimento das preexistências, no lugar da antiga política de remoção. Podemos assumir que o programa representou, de fato, a primeira experiência de política pública organizada de planejamento abrangente e criou um paradigma, inclusive internacional, na busca de articular as favelas à cidade. Data justamente 
do primeiro período do programa a consolidação do uso de um novo termo para designar as favelas - "comunidades" -, como vêm sendo chamadas desde então.

Por outro lado, como tanto se escreveu a respeito, uma política habitacional pautada na reorganização físico-espacial de uma área carente não é capaz, por si só, de resultar na integração social como reclamada pelo programa. Mais ainda, embora ela possa contribuir para o reconhecimento de certos grupos de atores, ela seria evidentemente incapaz de reverter de uma hora para a outra uma situação de profundas assimetrias sociais.

\section{Programa de Aceleração do Crescimento - PAC}

A questão das favelas no Rio de Janeiro ganhou novo impulso recentemente no segundo governo do presidente Luis Inácio Lula da Silva (2007-10), quando foi criado o Programa de Aceleração do Crescimento - PAC (lançado em janeiro de 2007) para estimular o desenvolvimento econômico e social do país através do investimento em infraestrutura nas áreas de transporte, energia, saneamento, habitação e recursos hídricos. O PAC é uma política pública do Governo Federal, mas que se orienta localmente de acordo com as especificidades das diferentes regiões e estados. No governo atual da presidente Dilma Rousseff (2011-) o programa vem tendo continuidade através do PAC2 e, mais recentemente, através do PAC3.

No Rio de Janeiro, o programa envolve o Governo do Estado do Rio de Janeiro, o Ministério das Cidades e a Caixa Econômica Federal. Entre outras ações, o PAC selecionou vários assentamentos "subnormais" a serem contemplados, entre os quais as três favelas: Pavão-Pavãozinho/Cantagalo, Complexo do Alemão e Favela da Rocinha. Estas favelas receberam verbas do setor de infraestrutura social e urbana do PAC-RJ, no valor de aproximadamente R\$ 1,2 bilhões (US\$ 525 milhões), do total de R\$ 125,7 bilhões (US\$ 55 bilhões) dos investimentos do programa para o estado até 2010. (http://www.brasil.gov.br/pac/relatorios/estaduais/rio-de-janeiro-1).

$\mathrm{O}$ PAC da Infraestrutura Social e Urbana dá sequência à política de intervenções em favelas na cidade do Rio de Janeiro com a grande diferença, em relação às intervenções anteriores do Favela-Bairro, no que diz respeito à sua abrangência. Assim, na identificação das áreas consideradas prioritárias de investimento, o PAC dá ênfase a grandes aglomerados, conjuntos de favelas em áreas de localização estratégica na cidade. Outra grande diferença é o processo de elaboração dos projetos. Enquanto o Favela-Bairro foi fruto de projetos elaborados por uma diversidade de equipes multidisciplinares, todas selecionadas em concurso público organizado pelo Instituto de Arquitetos do Brasil, o PAC buscou fazer uso 
de projetos e estudos já existentes, contratando diretamente arquitetos e urbanistas. A questão da habitação também foi tratada em uma escala diferente das experiências anteriores, agindo de forma contundente na eliminação das áreas precárias, oferecendo grande quantidade de novas unidades com condições dignas de moradia. O PAC também atrela, através da Caixa Econômica Federal, a liberação dos financiamentos para as intervenções urbanísticas em favelas à regularização fundiária.

Nas três comunidades citadas foram realizadas obras nas redes de abastecimento de água, esgotamento sanitário, drenagem, iluminação pública, além de alargamento e pavimentação de ruas, construção de novas unidades habitacionais e melhorias nas existentes e construção de equipamentos públicos.

No que se refere à mobilidade, o diferencial do PAC consiste na elaboração de intervenções que buscam estabelecer conexões com a rede de transporte urbano existente, além de atuar na escala local através da estratégia anteriormente estabelecida de alargamento e conectividade de cada área ao sistema viário.

Entre as comunidades contempladas pelo programa, nos três casos escolhidos para serem apresentados, as questões de mobilidade urbana tiveram destaque, contribuindo para a discussão sobre os modos de integração das favelas com a cidade formal e sobre novos modos de transporte e de deslocamento.

\subsection{PAC Complexo do Alemão}

O Complexo do Alemão localiza-se na região da Serra da Misericórdia, Zona Norte do Rio de Janeiro, possui uma população de aproximadamente 80 mil pessoas que habitam na conurbação de 15 favelas (1-Estrada do Itararé, 2-Itararé, 3-Joaquim de Queiroz, 4-Morro da Baiana, 5-Morro das Palmeiras, 6-Morro do Adeus, 7-Morro do Alemão, 8-Morro do Piancó, 9-Mourão Filho, 10-Nova Brasília, 11-Parque Alvorada, 12-Relicário, 13-Rua 1 pela Ademas, 14-Rua Armando Sodré, 15-Vila Matinha) (SABREN < http://portalgeo.rio.rj.gov.br/sabren/index.html>).

O Complexo do Alemão havia sido objeto de um Plano de Desenvolvimento Urbanístico em 2001, desenvolvido através da Secretaria de Habitação da Prefeitura (Secretaria de Habitação, Prefeitura do Rio de Janeiro, 2004). O Plano do Complexo do Alemão surgiu como consequência dos conhecimentos adquiridos nas experiências com as grandes favelas e se apresenta como um Plano Diretor, propondo-se a estabelecer ações de planejamento em um horizonte de tempo maior do que aquele utilizado pelos projetos do 
Favela-Bairro. As intervenções do PAC no Complexo do Alemão, com valor global de R\$ 896 milhões (US\$ 392 milhões), fazem uso desse estudo anterior agregando alterações, nas quais a mobilidade ganha destaque com a implantação do primeiro teleférico em favelas no Rio de Janeiro.

Figura 3. Mapa da rede de teleférico do Complexo do Alemão.

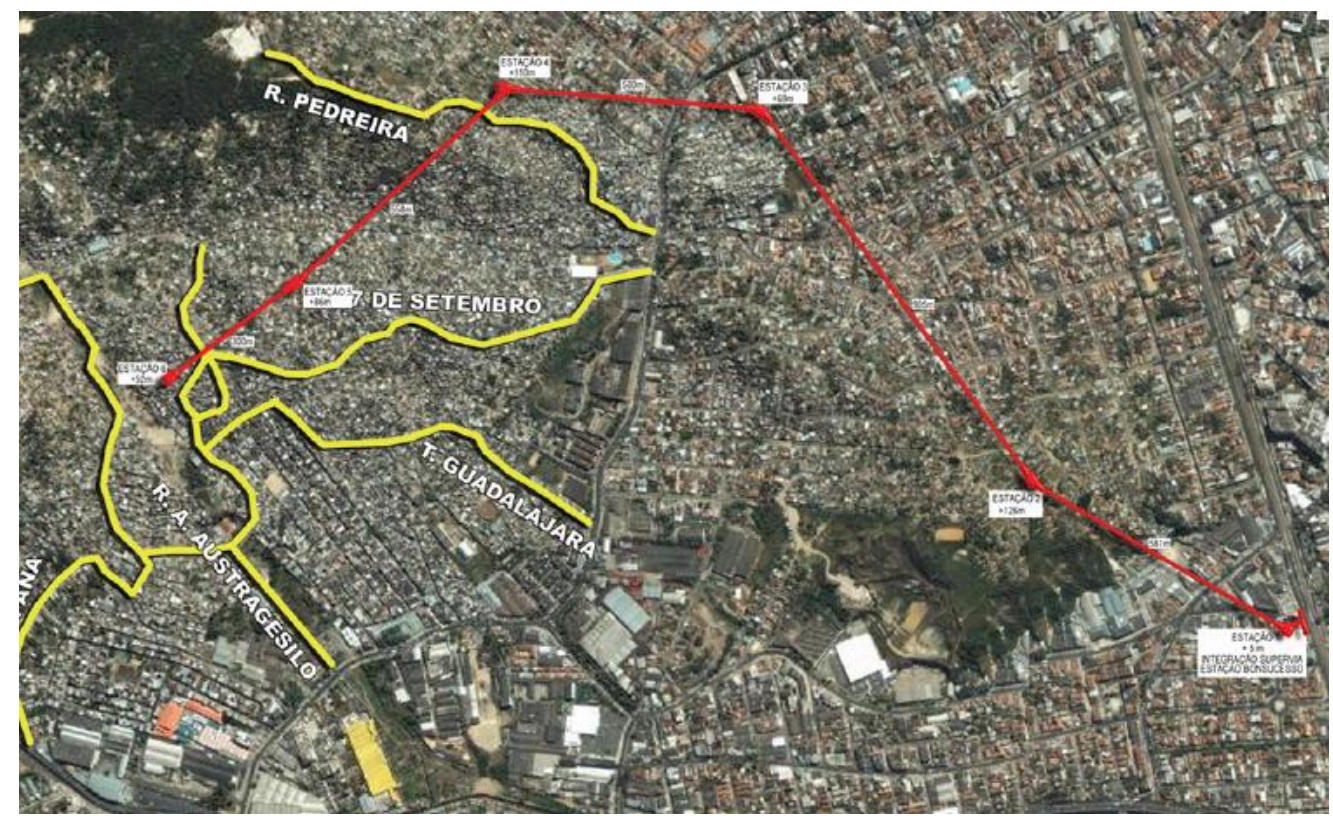

Fonte: Domínio público na internet.

A referência para a implantação do sistema de teleférico no Rio de Janeiro teve como inspiração as intervenções realizadas em Medellín, na Colômbia, e, segundo o arquiteto Jorge Mario Jáuregui, autor do projeto, a sua implantação:

(...) Implica um novo tratamento para a questão do transporte público, concebido como parte do sistema urbano metropolitano que garante a conexão entre as partes componentes do Complexo ao mesmo tempo que o recoloca no contexto urbano. No relativo à mobilidade, o teleférico se incorpora como parte central do sistema de transporte que irriga toda a área de intervenção. Este sistema de teleférico atende às características demográficas e topográficas do local, oferecendo redução do tempo de viagem e sistema de mobilidade não poluente.

(http://www.jauregui.arq.br/favelas_alemao.html)

O sistema de teleférico, inaugurado em 7 de julho de 2011, faz um percurso de quase 3,5 km conectando 6 estações: Bonsucesso, Morro do Adeus, Baiana, Alemão, Itararé e Palmeiras. A Estação de Bonsucesso é o ponto inicial do percurso, onde há a integração com uma estação de trem da Supervia, de mesmo nome. O sistema é composto de 152 cabines com capacidade para oito passageiros sentados e dois passageiros de pé, tendo sido projetado para 
atender até 30 mil passageiros por dia. O sistema de teleférico inclui também o conceito de "Estação Social" que abriga equipamentos comunitários, com a proposta de funcionarem como "polos de cidadania", com espaços de lazer, educação e cultura. ${ }^{1}$

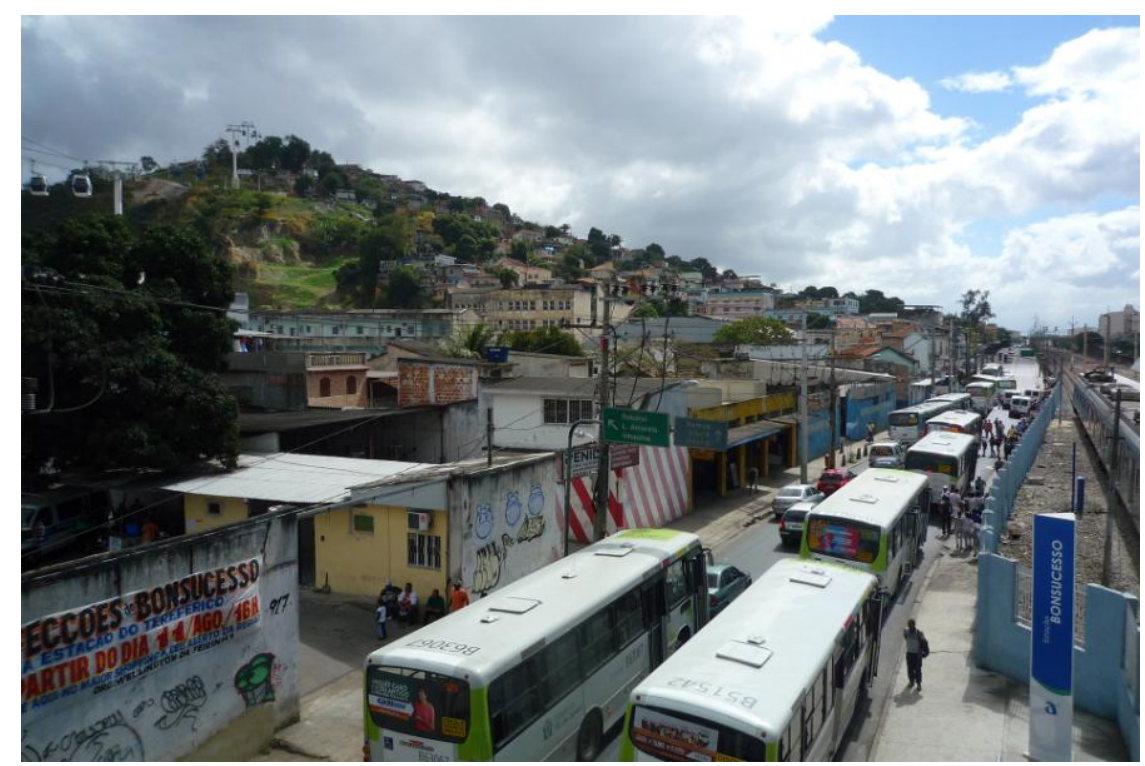

Foto 3. Acesso ao sistema de teleférico do Complexo do Alemão, Estação de Trens de Bonsucesso à direita. Fonte: Arquivo pessoal das autoras.

A implantação das estações do teleférico implicou também o desafio de realocar aproximadamente 2000 famílias para a implantação dos 24 pilares que sustentam o sistema de cabos. Quase a metade (920 famílias) foi reassentada dentro da própria comunidade em novas residências. Estas intervenções, ao que se somam as obras de implantação de infraestrutura de serviços públicos (água, esgoto, drenagem, pavimentação etc.), foram objeto de ampla divulgação por parte dos governos federal e estadual desde o lançamento do projeto, estendendo-se até após a sua inauguração ${ }^{2}$.

O vídeo de divulgação do projeto sublinha que “...o morador que levava 50 minutos de Bonsucesso até Palmeiras, agora pode efetuar a viagem de ponta a ponta em apenas 16 minutos." Contudo, após a passagem dos momentos inaugurais, o alcance do sistema tem tido

\footnotetext{
${ }^{1} \mathrm{Na}$ Estação do Adeus a população conta com uma sala de leitura e serviços bancários. Na Estação Baiana está localizado o POUSO (centro de orientação urbanística da Prefeitura) responsável por orientar e fiscalizar o cumprimento das normas locais. Na Estação Alemão, está implantado um Centro de Referência da Juventude, agência do INSS e espaço da Secretaria de Cultura. Na Estação Itararé está localizado o Centro de Serviços que abriga os Correios e Posto do DETRAN. Antes de chegar à Estação Palmeiras, um trecho de linhas de transmissão da Light foi enterrado, garantindo o trânsito seguro das cabines. Nesta Estação está localizada a Biblioteca Pública que conta com um vasto acervo de livros, salas de leitura individuais e coletivas.

${ }^{2} \mathrm{http}: / / \mathrm{www}$.youtube.com/watch?NR=1\&feature=endscreen\&v=E-cFI6Qr2wY e

http://www.youtube.com/watch?v=1EMO8nskyTg
} 
outro tipo de repercussão. Em matéria veiculada em vários canais de comunicação, ${ }^{3}$ indica-se que somente cerca de sete mil moradores se inscreveram para usar gratuitamente o teleférico, aproximadamente $10 \%$ da população.

Embora a iniciativa de articular um novo meio de transporte com os já existentes seja um diferencial importante no que se refere à mobilidade nas obras do PAC do Complexo do Alemão, o projeto implantado parece não estar à altura da eficiência da divulgação feita pelos órgãos oficiais.

No caso, o ponto falho quanto ao sistema de teleféricos parece residir no fato de que a sua implantação aparenta não ter tido compatibilidade com o plano urbanístico e com a própria trama viária de cada uma das favelas que compõem o Complexo do Alemão. Isto fica evidenciado pelo menos em duas decisões de projeto implementadas: a primeira quanto à locação dos pilares de sustentação e a segunda quanto à localização das estações.

A abertura de novas vias exclusivamente para a implantação dos pilares, por exemplo, certamente pode ocasionar a expansão das favelas em áreas que até aquele momento permaneciam não urbanizadas, inclusive por apresentarem risco geológico. Para resolver este problema criou-se, em alguns casos, áreas de lazer próximas às áreas dos postes de sustentação, acarretando a criação de espaços de uso coletivo em pontos distantes das áreas mais densas, onde seriam mais necessárias.
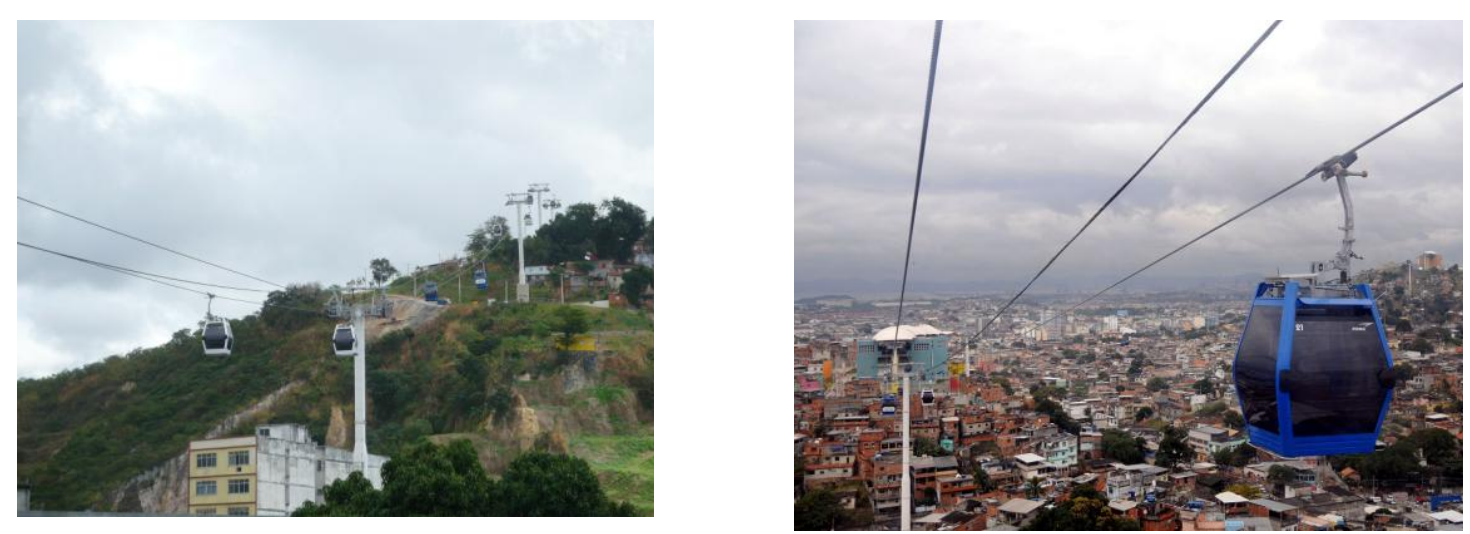

Fotos 4, 5 - Teleférico do Complexo do Alemão. Fonte: Arquivo pessoal das autoras.

No caso das estações, sua localização no topo dos morros, por exemplo, acaba por torná-las de difícil acessibilidade para a população que habita nas cotas mais baixas. Esta

\footnotetext{
${ }^{3}$ http://g1.globo.com/rio-de-janeiro/parceiro-rj/noticia/2012/01/parceiro-do-rj-mostra-dificuldades-no-acesso-aoteleferico-do-alemao.html
} 
seria obrigada a vencer, a pé, longas escadarias - às vezes de até 90 metros de altura - para conseguir acessar as estações do teleférico.

Passados oito meses da inauguração do teleférico do Complexo do Alemão, feita pela presidente Dilma Rousseff e pelo governador do Estado do Rio de Janeiro, Sérgio Cabral, divulga-se que cerca de 1,1 milhão de pessoas já foram transportadas, o que contabiliza aproximadamente 4.500 pessoas/dia. Em maio de 2012, a Supervia festejou o transporte de 2 milhões de pessoas, o que aumentaria esta cifra para aproximadamente 5.300 pessoas/dia. Mais recentemente, o site da Supervia registra a marca de 7 milhões de passageiros transportados, o que equivaleria, a aproximadamente 8.500 pessoas/dia - o que indica um aumento gradual de passageiros transportados/dia, um valor que, não obstante, representa menos de um terço do que o sistema instalado pode oferecer.

Embora esteja articulado a uma das principais redes de transporte da cidade, que são os trens, o sistema de teleféricos funciona como transporte complementar para um pequeno número de usuários. A sua administração é feita pela empresa Supervia, a mesma que administra o sistema de trens urbanos de subúrbio, que transportou em 2012 aproximadamente 529 mil passageiros/dia. Em definitivo, o número de passageiros transportados pelo teleférico está muito aquém tanto da capacidade do sistema como da demanda da população residente, que é de 80 mil pessoas.

Deve-se assinalar que as tarifas não são um impeditivo do seu baixo uso, visto que há integração tarifária com o bilhete de trens cujo custo unitário é de R \$2,90 (US\$ 1,27); com o bilhete de ônibus municipal o valor é de R \$3,95 (US\$ 2,16) e, enfim, com o bilhete de ônibus intermunicipais, que alcançam a região metropolitana, cujo valor pode chegar ao máximo de $\mathrm{R} \$ 4,95$ (US\$ 2,16). A tarifa para usar apenas o teleférico tem o custo avulso de R \$ 1,00 (US\$ 0,44). Em contrapartida, apesar de custar o dobro do teleférico, as motos-táxi, permanecem como um meio de transporte amplamente utilizado pela população para acessar suas casas a partir de terminais de ônibus ou trens. Parece, portanto, que a implantação do teleférico no Complexo do Alemão ocorre sem um estudo prévio da localização da demanda origemdestino da sua população e os motivos dos deslocamentos.

A dimensão imagética das intervenções, por outro lado, vem sendo intensamente explorada nas publicidades de divulgação política destas iniciativas. De fato, a linha de postes com seus cabos e as cabines de passageiros podem ser observadas muito além das proximidades da favela, de vários pontos da Zona Norte do Rio de Janeiro, em especial de uma das principais vias expressas, a Linha Vermelha, que conecta o Aeroporto Internacional Antonio Carlos Jobim às áreas mais valorizadas da cidade, o Centro, a Zona Sul e a Barra da 
Tijuca. Outra percepção que o teleférico permite é a visão de cima, feita pelo turista ou pelo próprio morador. O primeiro tem passado a utilizar o teleférico como meio de conhecer ambiências antes quase impossíveis de visitar, enquanto que, para os moradores, vem se constituindo numa valorização daqueles que têm suas casas em seu percurso, como narra matéria na Revista de Domingo ( $O$ Globo, n. 393, 3 fevereiro 2012) de um dos principais jornais cariocas.

\subsection{PAC Pavão-Pavãozinho/Cantagalo}

As comunidades do Pavão-Pavãozinho e do Cantagalo - ou PPG, abreviação utilizada pelos moradores - constituem duas favelas conturbadas e estão localizadas no coração da Zona Sul carioca, na encosta sul da Serra de Copacabana-Botafogo, nos limites entre os bairros de Ipanema e Copacabana, a partir de onde se fazem seus acessos.

A história de ocupação desse morro remonta à ocupação da orla litorânea do Rio de Janeiro, no início do século XX, e está relacionada ao nascimento, primeiro do bairro de Copacabana, pelo surgimento do bairro de Ipanema, e depois, do Leblon. Copacabana teve seu auge de popularidade nos anos 1950 e Ipanema se estabeleceu como um dos bairros litorâneos mais valorizados da Zona Sul carioca a partir da década de 1960. O surgimento desses novos bairros se dá em um contexto onde a população carioca passa a ver como símbolo de status social a proximidade com o mar e um modo de vida calcado no despojamento. Esses bairros precisavam, por outro lado, de mão de obra para os diversos serviços: construção civil, hotelaria, serviços domésticos etc. É desta forma que uma população pobre se instala nas fraldas da Serra de Copacabana-Botafogo, onde desde um primeiro momento encontram facilidades de transporte público, mas sem nenhuma infraestrutura de serviços públicos (água, esgoto, luz). 
Figura 4. Pavão-Pavãozinho/Cantagalo, 2010.

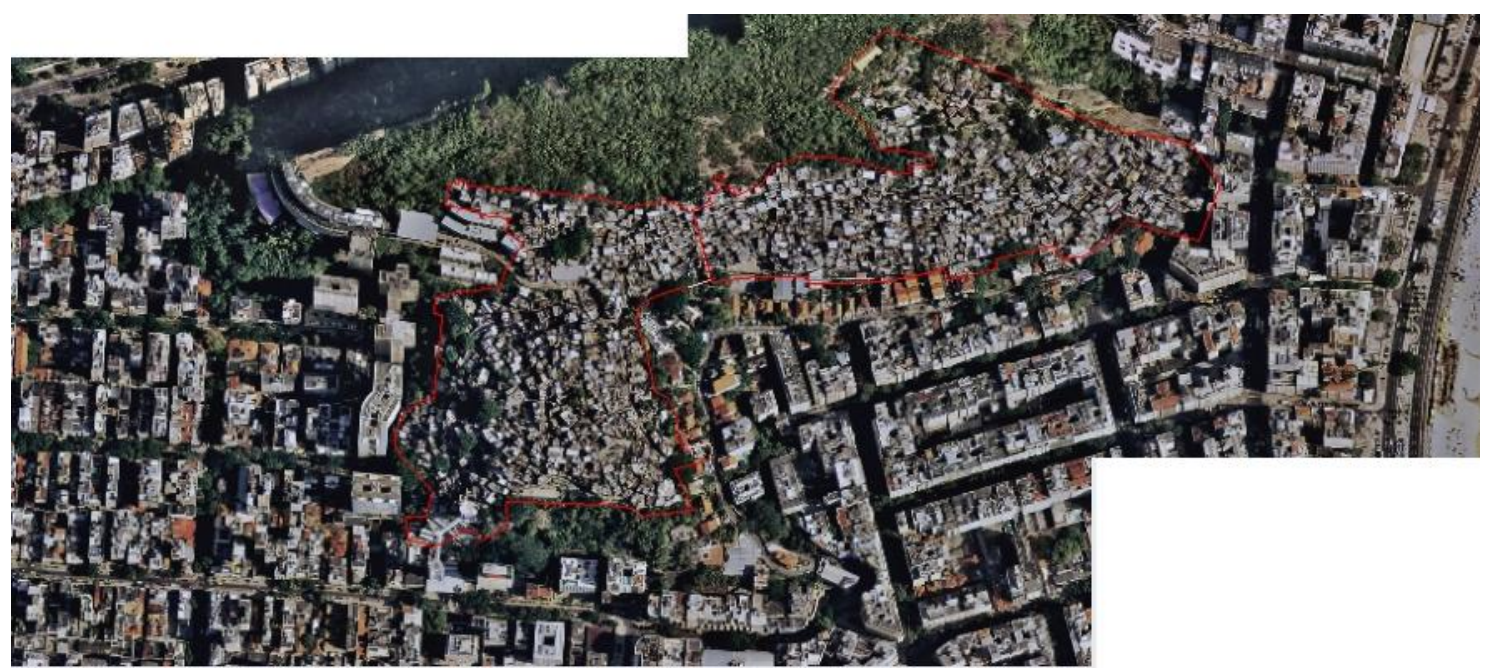

Fonte: Sistema de Assentamento de Baixa Renda-SABREN, Instituto Pereira Passos-IPP, Prefeitura da Cidade do Rio de Janeiro, 2010. 〈http://portalgeo.rio.rj.gov.br/sabren/>.

Na década de 1960, diferentemente da política de remoção que ocorreu em outras favelas da Zona Sul, empreendida pelo governador Carlos Lacerda, as favelas do Cantagalo e Pavão-Pavãozinho tiveram obras de urbanização com melhorias em suas escadarias e no abastecimento de água. Em 1984, no primeiro mandato de Leonel Brizola no Governo do Estado do Rio de Janeiro (1983-1987), foram realizadas algumas obras de urbanização das quais se destacam a abertura da Estrada do Cantagalo e a implantação de um plano inclinado no Pavão-Pavãozinho. Estas comunidades não foram objeto de projetos e intervenções pelo programa Favela-Bairro, embora sua população se enquadrasse dentro do número de domicílios das favelas médias, contando hoje com o total de aproximadamente 28 mil moradores, em torno de 8 mil domicílios.

De certo, a sua localização, colada a bairros centrais da Zona Sul carioca, e a forte presença de traficantes e crime organizado a partir da década de 1980, misturada à presença de mão de obra para a classe média moradora do asfalto, fez com que a sua urbanização fosse sendo adiada, estabelecendo-se uma convivência marcada pela dissimulação e a negociação constante da tensão entre moradores do morro e do asfalto, no lugar de intervenções mais incisivas. As obras do PAC, lançadas pelo presidente Luiz Inácio Lula da Silva em 2008, e inauguradas em julho de 2010 pelo governador do Estado, Sérgio Cabral, e pelo prefeito do Rio de Janeiro, Eduardo Paes, constituíram-se, portanto, na primeira intervenção de caráter global nestas comunidades.

Os projetos que deram origem às intervenções do PAC foram elaborados por técnicos do governo do Estado do Rio de Janeiro para as empresas construtoras - neste caso a 
Construtora OAS - que, por sua vez, subcontratou o desenvolvimento dos projetos ao escritório de arquitetura ArquiTraço.

Nos vídeos divulgados por órgãos federais sobre as obras concluídas, ressalta-se a instalação de redes de esgoto e sua ligação às redes formais, a instalação de uma estação elevatória e um novo reservatório de água, a regularização fundiária através do cadastramento de aproximadamente 4.500 famílias, as novas unidades habitacionais e, finalmente, as melhorias de acessibilidade e mobilidade. A abertura de novas vias que alcançam até o topo da comunidade e a implantação de um elevador, em duas torres, de 64 e 26 metros de altura, interligado à estação de metrô General Osório, consistem nas intervenções de maior envergadura, além do tratamento das escadarias existentes e a urbanização dos espaços públicos com a implantação de pequenas praças ao longo dos percursos. ${ }^{4}$

Avalia-se que o maior problema para a mobilidade dos habitantes do Cantagalo/ Pavão-Pavãozinho está na forte pendente do local, com diferença de nível, a partir das ruas íngremes de acesso, de mais de 100 metros. A ausência de um sistema viário contínuo é tratada no projeto de forma a dar maior conectividade com a cidade formal. O Beco do Amor Perfeito, por exemplo, é um novo acesso implantado pelo lado de Copacabana, que rapidamente de transformou em uma das principais conexões de pedestres.
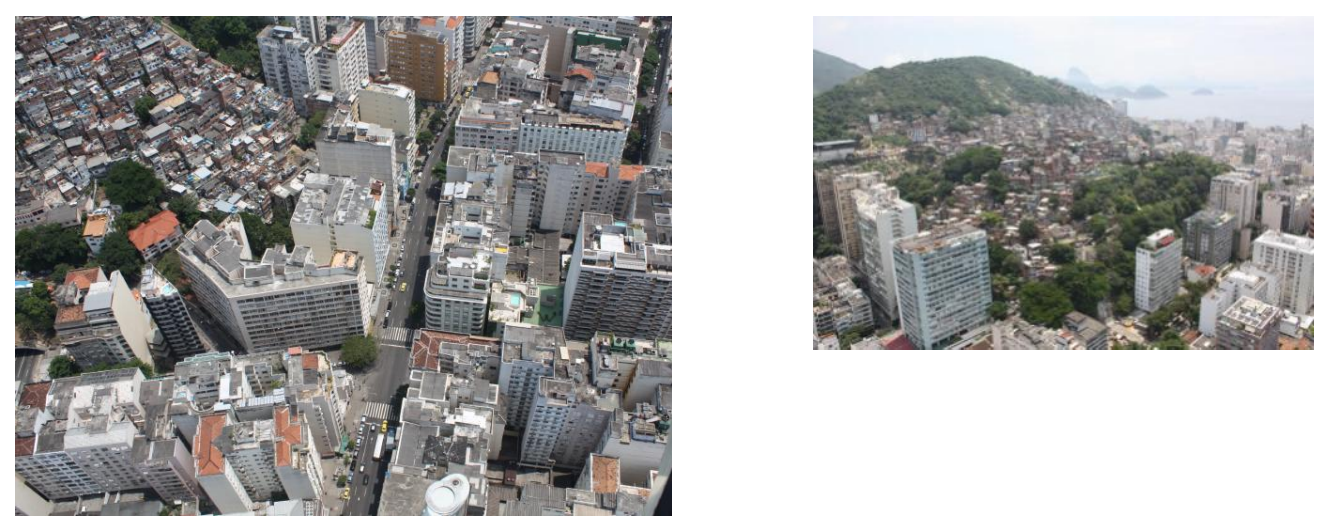

Fotos 6, 7 - Cantagalo / Pavão-Pavãozinho. Fonte: Grupo de Pesquisa Quapá-Sel, USP, 2008.

Entretanto, constata-se que muitas das intervenções que constam nos vídeos de divulgação oficiais não estão realizadas ou estão inconclusas. Muitas ruas importantes para a ligação da favela com as ruas existentes ainda restam a ser implantadas e somente a primeira torre do elevador do Cantagalo - que faz a ligação entre a estação de metrô e a cota intermediária da favela - está em funcionamento. Esta torre possui 2 elevadores panorâmicos

\footnotetext{
${ }^{4} \mathrm{http} / / / \mathrm{www}$.youtube.com/watch?v=8r2QBbx-rBk e http://www.youtube.com/watch?v=MCop9dPNXW0\&feature=related
} 
com a capacidade de transportar 50 pessoas, por viagem. Não há custos para sua utilização, e é frequentemente realizada por turistas que se dirigem ao denominado Mirante da Paz, localizado no topo da torre para desfrutar de impressionantes vistas.

À semelhança das obras do PAC do Alemão, as intervenções do PAC Cantagalo/ Pavão-Pavãozinho se diferenciam das intervenções anteriores no que tange às propostas de mobilidade urbana nas favelas pela busca de interligar novos equipamentos com a rede de transporte público da cidade e neste sentido constituem novas abordagens, mais abrangentes e articuladas. Entretanto, no caso do elevador poderíamos considerar a ausência de uma maior integração com a dinâmica interna da favela.

A falta de relação entre os projetos do elevador e de urbanização de largos e praças faz com que a chegada da passarela que liga a torre à comunidade se faça em um local exíguo, incapaz de comportar e guiar o fluxo de pessoas que o elevador polariza. A encosta não possui tratamento paisagístico e de acessos condizente com a escala grandiosa da intervenção da torre do elevador nem a articula às primeiras casas da comunidade. Trata-se de uma torre isolada de grandes dimensões cujas funções, além daquela de facilitar a acessibilidade dos moradores, parece sinalizar para o estabelecimento de uma nova ordem nas relações entre a população da favela e do asfalto. A presença de um mirante - ao qual só se tem acesso através de novas escadas! - tem levado inúmeros turistas locais e estrangeiros a conhecer a favela, pois a partir dele avista-se, com clareza e de longe, toda a multiplicidade e precariedade da favela. A incompletude atual dessa intervenção, sem o funcionamento da segunda torre de elevadores e sem a construção da via de acesso no topo do morro - sobre a qual se sabe que pode significar a demora de longos anos, até que que sejam finalizados -, mais uma vez, não constitui uma rede implantada.
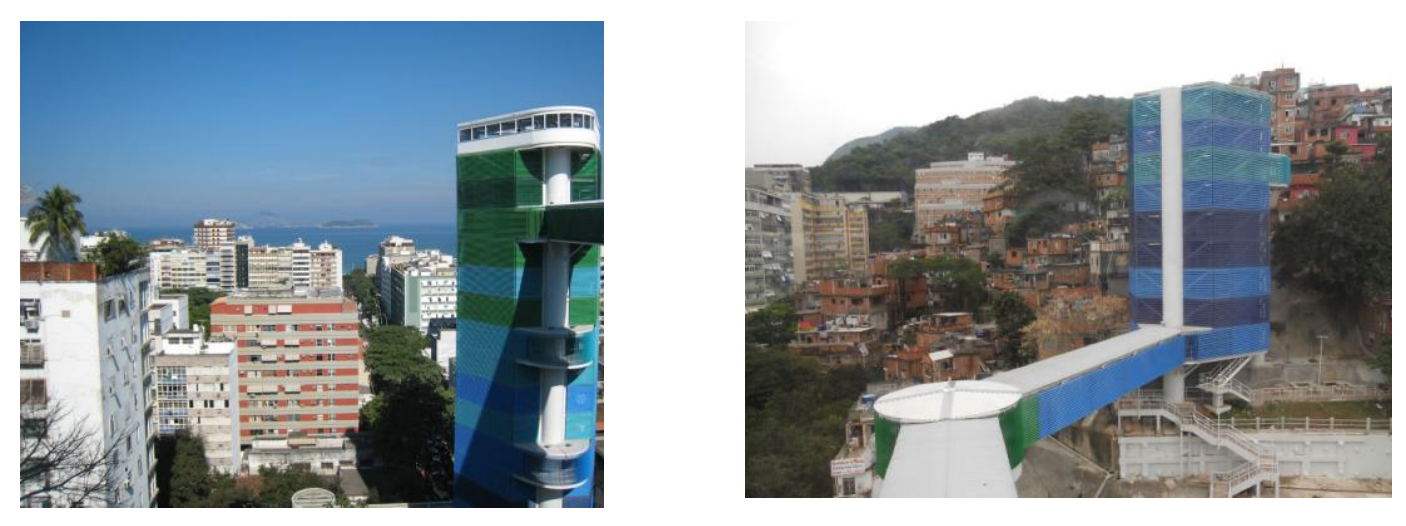

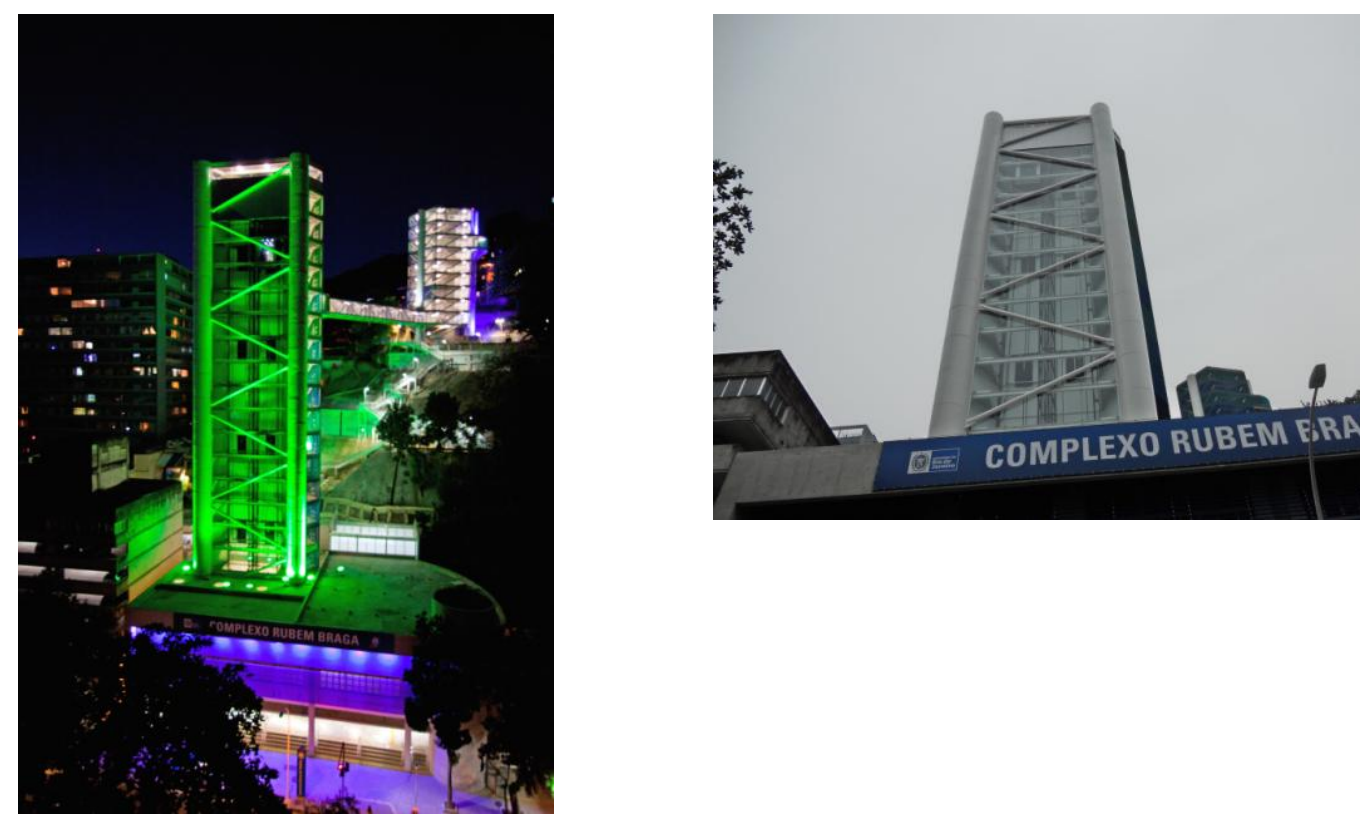

Fotos 8, 9, 10, 11 - Elevador Cantagalo / Pavão-Pavãozinho, 2011. Fonte: Arquivo pessoal das autoras.

Como não se cobra para a utilização do elevador, também não há registro do número de usuários que fazem uso do seu serviço diariamente. Desta forma, também não há como se avaliar a relação custo/benefício para os moradores da comunidade nem para a cidade, tendo em vista os custos realizados de $\mathrm{R} \$ 70$ milhões (US\$ 30,6 milhões) para a urbanização da favela, e de R\$ 478 milhões (US\$ 198,8 milhões) para a expansão da linha 1 do metrô, onde estão incluídos os custos para implantação dos elevadores.

\subsection{PAC Rocinha}

A Rocinha talvez seja a mais populosa e densa favela do Rio de Janeiro. Está composta por mais de 20 sub-bairros - que têm seus mais variados nomes de acordo com a tradição local de seus moradores - que contabilizam, segundo Censo Domiciliar realizado pelo trabalho social do PAC (2008/2009), 98.319 habitantes em 34.576 domicílios, com uma densidade de 2,9 hab/domicílio (GOVERNO DO ESTADO, 2012:79). Está localizada na encosta dos morros Dois Irmãos e Cochrane, entre os bairros de São Conrado e Gávea, que, junto com outros bairros vizinhos, acumulam a maior renda per capita, na Zona Sul da cidade. 
Figura 5. Plano Urbano da Rocinha.

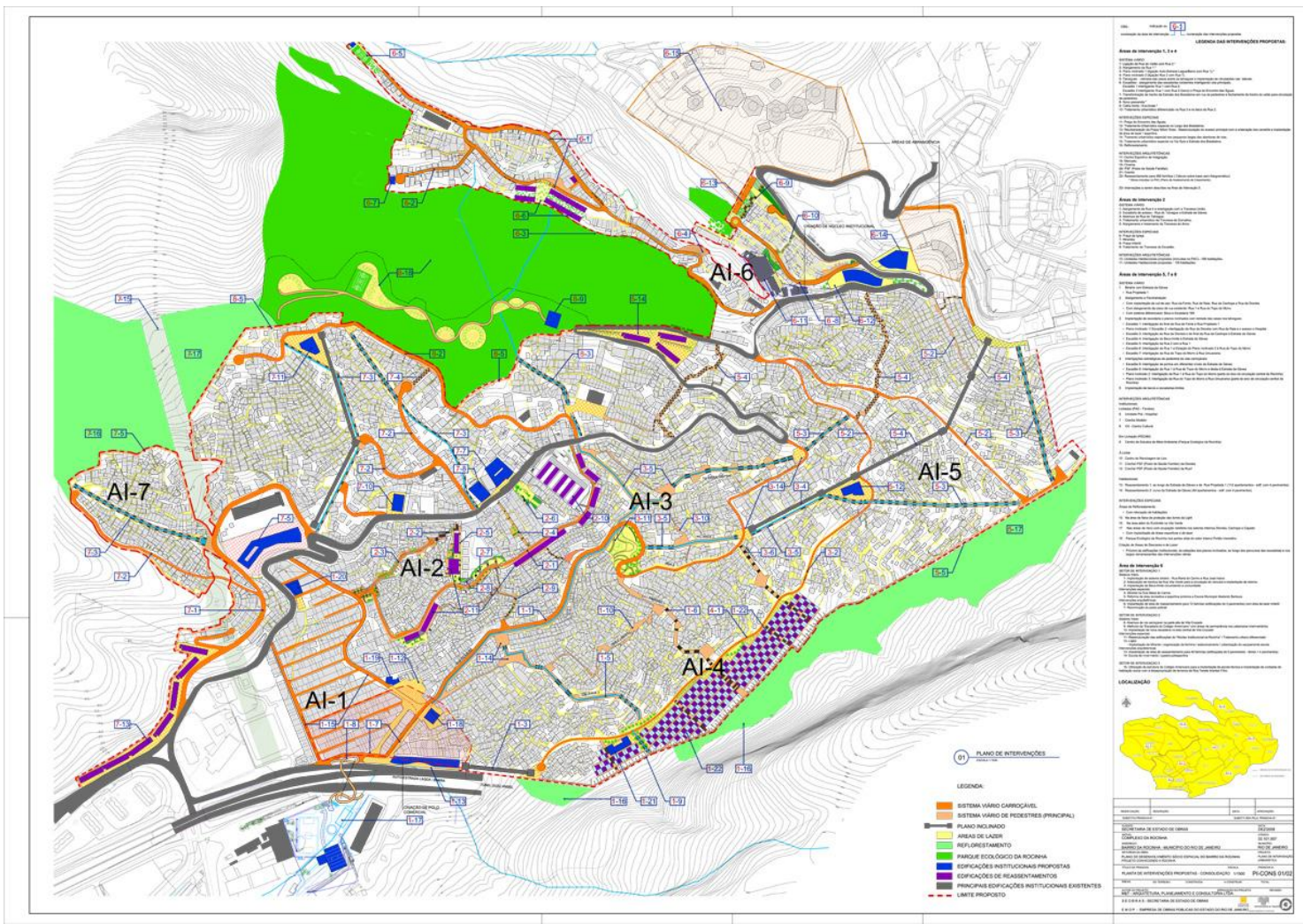

Fonte: MT Arquitetura, 2011.

O boom urbano da Rocinha aconteceu a partir da década de 1960, a reboque da política de remoção de favelas realizada nas áreas nobres próximas à orla. Desta forma, ao mesmo tempo em que muitas favelas eram removidas, muitos moradores que não desejavam ir para locais distantes de onde já trabalhavam na Zona Sul, migraram para outras áreas na própria Zona Sul. A isto se soma a migração de um grande número de pessoas vindas da Região Nordeste do Brasil, e também do interior do Estado para a capital.

Gradualmente os barracos de madeira e zinco foram sendo substituídos por casas de alvenaria, erguidas muitas delas com sobras de material de construção dos grandes condomínios de São Conrado e Barra da Tijuca, construídos a partir dos anos 1970. Este crescimento foi acompanhado de uma série de serviços, comércio e instituições comunitárias, que contribuem para culminar a instituição da Rocinha como categoria administrativa de bairro, pela Prefeitura, em 1993.

As intervenções do PAC têm origem no projeto escolhido através de Concurso Nacional de Ideias para a Urbanização da Rocinha, promovido pelo Governo do Estado através da SEMADUR - Secretaria de Estado de Meio Ambiente e organizado pelo Instituto de Arquitetos do Brasil. Realizado em 2005, do concurso se sagrou vencedora a equipe 
coordenada pelo arquiteto Luiz Carlos de Menezes Toledo, da MT Arquitetura. É oportuno lembrar que o concurso de ideias para a Rocinha surgiu como resposta a um evento marcante envolvendo a guerra do tráfego de drogas na cidade, em 2004. Na madrugada de uma sextafeira, 60 bandidos da Favela do Vidigal, também localizada no Morro Dois Irmãos, rumaram para a Rocinha para um acerto de contas com uma facção rival, acarretando o fechamento de vias e a morte de várias pessoas. Deste evento decorreu uma série de movimentações da sociedade civil para enfrentar a violência urbana, entre elas o concurso de ideias.

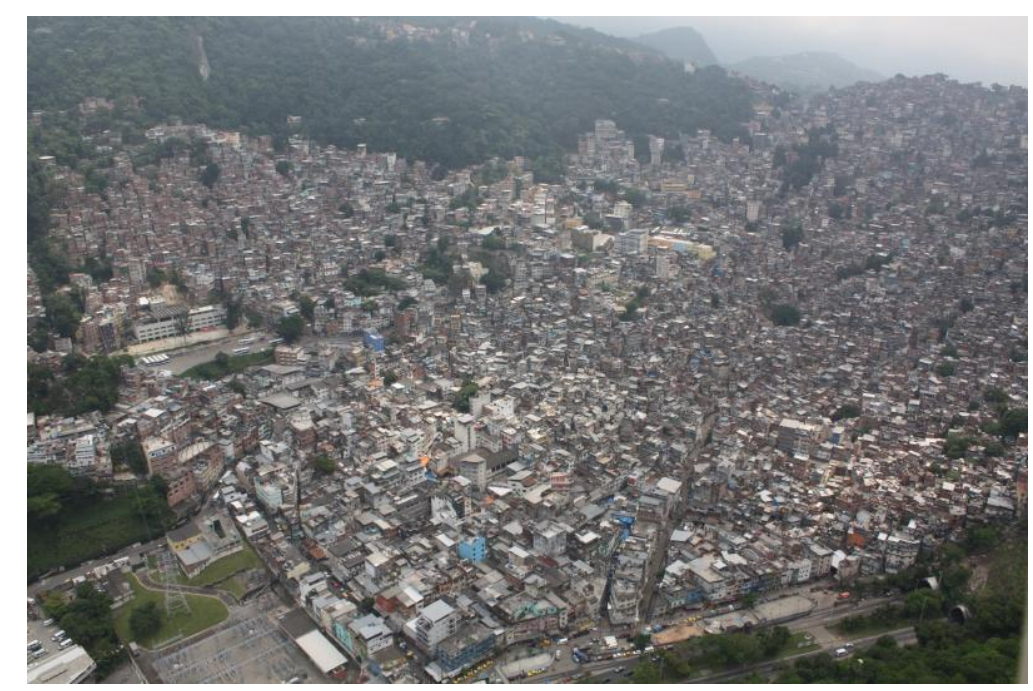

Foto 12 - Rocinha Foto Aérea. Fonte: Grupo de Pesquisa Quapá-Sel, USP, 2008.

As principais diretrizes apresentadas no concurso se baseavam em uma forma participativa de atuação para a urbanização de valas, a criação de acessos, a integração aos bairros vizinhos e a delimitação de uma área exemplar de atuação no miolo da comunidade (cidadeinteira.blogspot.com/2011/09/mobilidade-urbana-experiencia-da.htm, p. 43). As obras do PAC na Rocinha ocorreriam a partir de março de 2008, em meados do primeiro mandato do hoje re-eleito governador do Estado do Rio de Janeiro, Sérgio Cabral Filho, e alcançariam o valor de R\$ 267 milhões (US\$ 116,8 milhões). O PAC se baseia no projeto em desenvolvimento pelo escritório MT, que havia se instalado no local e promovido um processo decisório participativo, realizado a partir de reuniões comunitárias. O conjunto de obras que compõem o PAC Rocinha pode ser classificado em três esferas: a construção de novos prédios para serviços e equipamentos públicos - como creche, biblioteca e equipamentos esportivos -, as ações de urbanização, acessibilidade e saneamento e, enfim, a construção de unidades habitacionais. 
Entre as ações definidas para urbanização, acessibilidade e saneamento estão: a construção de uma nova passarela da Rocinha - projetada pelo arquiteto Oscar Niemeyer; o alargamento e a urbanização da Rua 4 - definida como área exemplar e acesso importante a vários sub-bairros; a criação de um sistema composto por cinco planos inclinados que possibilitará aos moradores se deslocarem da Gávea até São Conrado à pé, superando os trechos mais difíceis; entre outras medidas de reorganização e requalificação dos espaços públicos. As propostas de mobilidade para a Rocinha consistiram muito mais em melhorar a conectividade e acessibilidade intrafavela e em seus bordos do que a sua conexão com o sistema de transportes da cidade, como explica o arquiteto Luiz Carlos Toledo:

Na verdade os moradores da Rocinha se encontram bem servidos por linhas de ônibus e vans que passam pela Estrada Lagoa Barra, pela Rua Marquês de São Vicente e, até mesmo, cruzam a favela pela Estrada da Gávea. Entretanto, a movimentação dos moradores no interior da favela e os percursos e estratégias utilizados não eram tão óbvios quanto pareciam ser. (http://cidadeinteira.blogspot.com/2011/09/mobilidade-urbana-experienciada.html)

A observação da maneira como os deslocamentos são realizados definiram as estratégias de projeto:

Durante meses analisamos esses percursos para compreender as diferentes estratégias utilizadas pelos moradores para fazer compras, visitar os amigos, ir à escola e, principalmente, para trabalhar, dentro ou fora da favela. Chegamos à conclusão de que, se respeitássemos essas estratégias, poderíamos adotar medidas muito simples para melhorar, em muito, a mobilidade na Rocinha. (id.ib.)

Toledo destaca ainda que as propostas buscaram privilegiar a simplicidade e o baixo custo, principalmente, se comparadas com outras soluções adotadas, referindo-se aos custos do teleférico do Complexo do Alemão.
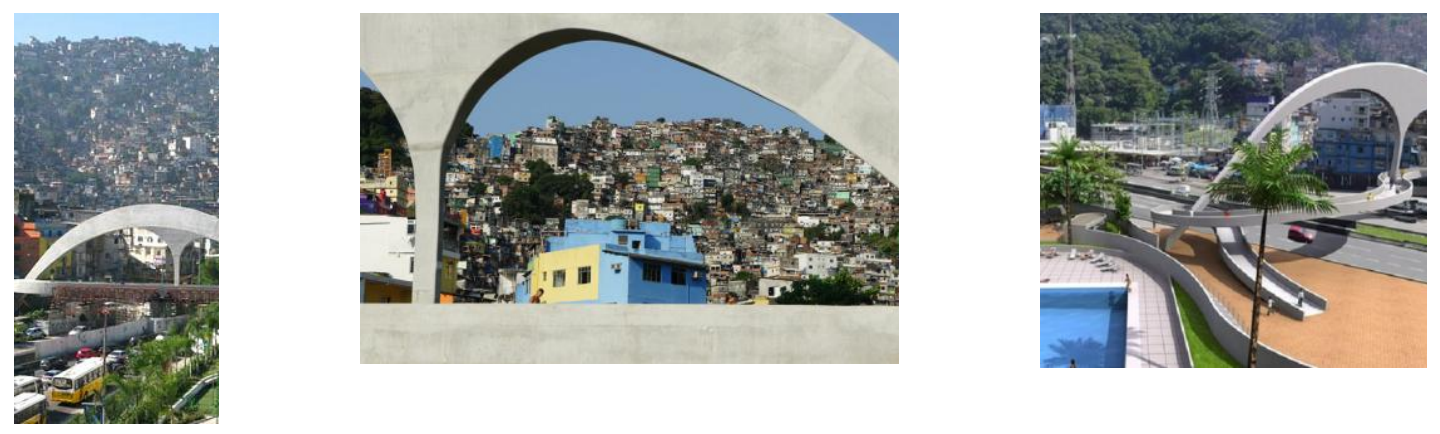

Fotos 13, 14, 15 - Passarela da Rocinha. Fonte: Domínio público na internet. 
Entre as intervenções que se apresentam como grande destaque está o alargamento da Rua 4, um antigo beco que variava de $60 \mathrm{~cm}$ a $80 \mathrm{~cm}$ de largura, que foi transformado através da desapropriação de 327 unidades de até cinco andares de altura - em uma via carroçável com largura variável entre 5 e 12 metros. A criação de um espaço compartilhado na rua consistiu também na recuperação de fachadas, arborização e paisagismo com criação de espaços de estar e lazer. A obra viária da Rua 4 vem também ao encontro de questões de saúde pública, tendo em vista o alto índice de casos de tuberculose na favela. Ainda, para abrigar as famílias que desejaram ser realocadas para sua execução, foram construídas 144 novas moradias. Estas intervenções vêm sendo amplamente divulgados pelos governos federal e estadual (http://www.youtube.com/watch?v=kG3r1A1TheM).

O sistema de planos inclinados, do qual fala o arquiteto, busca suavizar e encurtar os longos percursos que alguns moradores fazem para chegar às suas casas. De fato, o morador de áreas mais internas à favela é obrigado a fazer a transferência entre os ônibus ou as motostáxi e ainda enfrentar longa caminhada em escadarias até suas casas. O sistema de mobilidade proposto pelo projeto buscaria então compatibilizar os modais entre si, de forma a racionalizar os percursos.

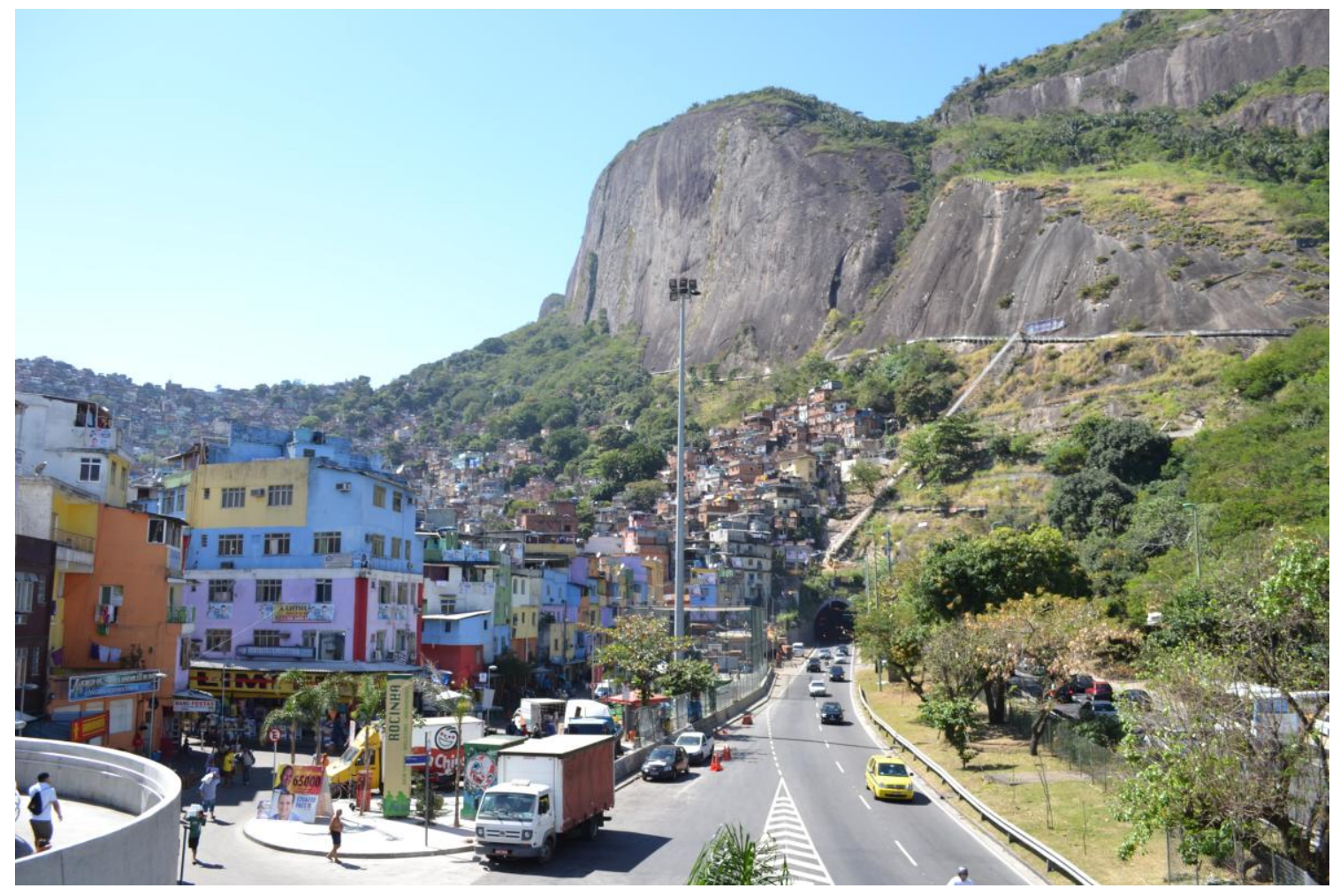

Foto 16 - Vista da Rocinha a partir da passarela, 2013. Fonte: Arquitraço arquitetura, 2013. 


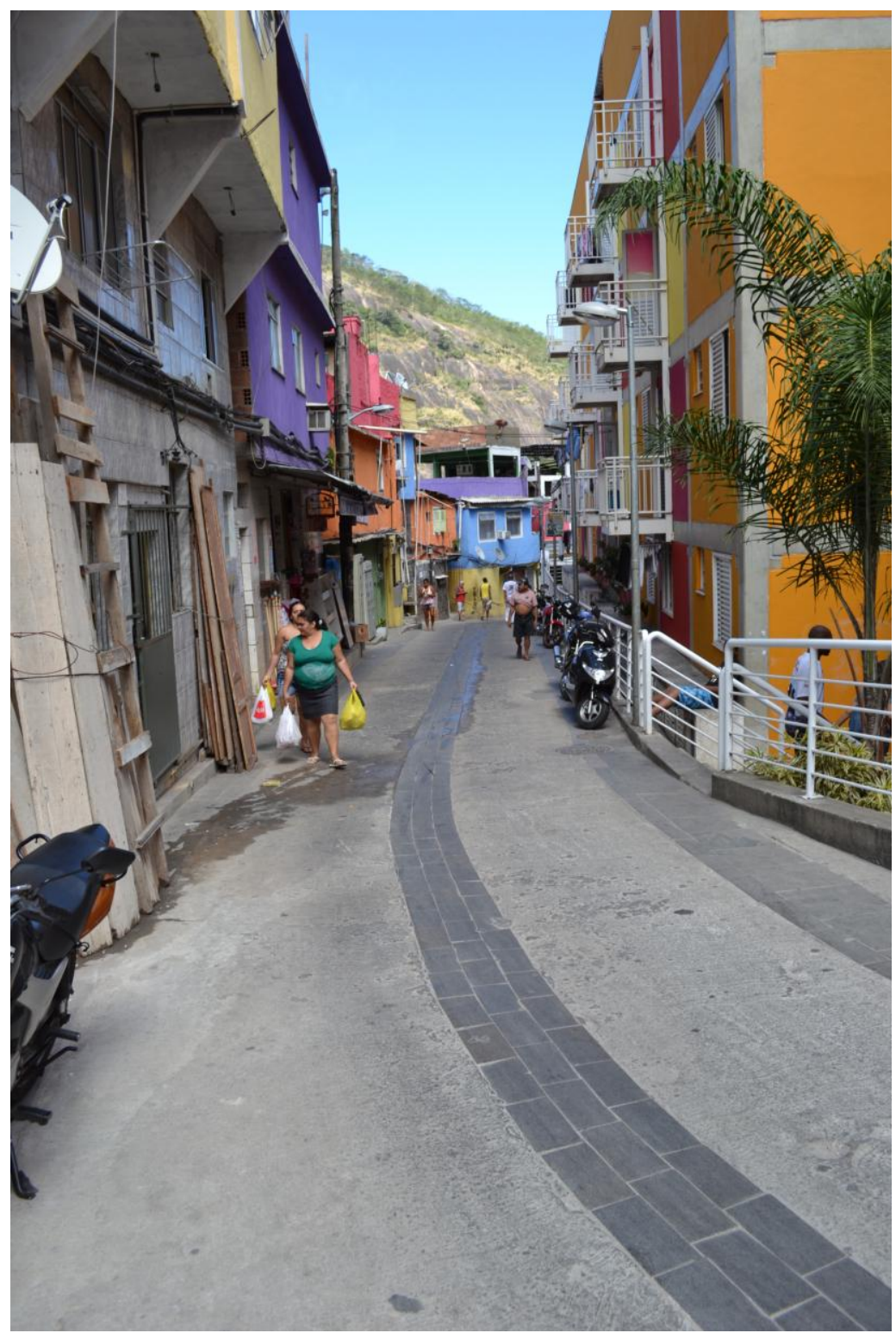

Foto 17 - Urbanização da Rua 4, Rocinha, 2013. Fonte: Arquitraço arquitetura, 2013.

A consistência do projeto radica-se, de certo, no processo participativo sobre o qual foram construídas as suas ações, originando também um Plano de Desenvolvimento Sustentável, empenhado no Trabalho Social com a criação de espaços de debate através dos Comitês Populares, reconhecendo e instrumentalizando a economia pujante do lugar. Toda a coerência interna, entretanto, parece escapar ao projeto na passarela encomendada ao arquiteto Oscar Niemeyer, localizada no local de maior visibilidade da urbanização, no acesso junto ao Túnel Zuzu Angel. A passarela cobre uma importante autoestrada com fluxo intenso de veículos, e garante acessibilidade ao portador de necessidades especiais, mas não possui nenhum mecanismo que amenize a poluição sonora ou a incidência do sol dos trópicos. Para os 50 metros de vão, o arquiteto projetou um pórtico com um tirante central, com desenho 
recorrente a alguns outros de seus projetos, como por exemplo, o arco da Praça da Apoteose, no sambódromo do Rio. A estrutura em pórtico, sem apoios centrais, parece negligenciar o lugar, deixando de utilizar o canteiro central existente para um apoio, que certamente diminuiria os custos da estrutura. Os acessos à passarela encontram-se bem localizados, conectando-se aos pontos de ônibus e aos equipamentos.

Apesar de sua acertada conectividade e da elegância de traços, a passarela parece lançar mão da mesma manobra utilizada pelo teleférico do Complexo do Alemão e pelo elevador do Pavão-Pavãozinho/Cantagalo, em tentar explorar a visibilidade do projeto e o apelo imagético da intervenção.

Ora, em que pese o criterioso projeto definido pelo escritório MT para a construção dos 6 planos inclinados, neste momento pelo qual passa a cidade do Rio de Janeiro - de intervenções pesadas em infraestrutura por toda parte com vistas a prepará-la para receber os grandes eventos que acontecerão em 2014 e 2016 -, a Prefeitura do Rio publicou no final de 2011 um edital de projeto onde se inclui a implantação de um teleférico na Favela da Rocinha. Considerando-se que o projeto anterior era resolvido todo ele no nível do chão, através de um sistema de vias carroçáveis, escadarias e planos inclinados, o teleférico se coloca como uma solução midiática, e de certo mais custosa do que a anterior. Na urbanização das favelas se impõe, pois, de forma indispensável, a reflexão sobre o verdadeiro papel da mobilidade, que certamente deve se pautar menos por sua publicidade e mais pela ampliação da oferta do poder se deslocar com qualidade.

\section{Conclusão}

As intervenções recentes efetuadas, através do PAC de Infraestrutura Social e Urbana, em três grandes favelas no Rio de Janeiro são indícios de um novo momento da urbanização de favelas, que acompanha o forte crescimento econômico do Brasil e o momento de polarização de atenção da cidade, através dos grandes eventos.

Consideramos que estas intervenções vêm sendo realizadas com grande largueza de recursos públicos, nos quais a importância do planejamento e dos critérios de decisão que conduzem os projetos podem ficar relegados a um segundo plano. O PAC introduziu uma nova dimensão da mobilidade urbana, pouco explorada em programas anteriores, qual seja a intenção de colocar em rede os variados modais de transporte existentes com a urbanização intrafavela. Por outro lado, a falta de articulação do projeto de mobilidade urbana com o projeto de urbanização é flagrante em todos os casos. A oferta de mobilidade para todos é fundamental para uma sociedade que espera diminuir suas assimetrias sociais. 
Gráfico 1. População das Favelas, 2011.

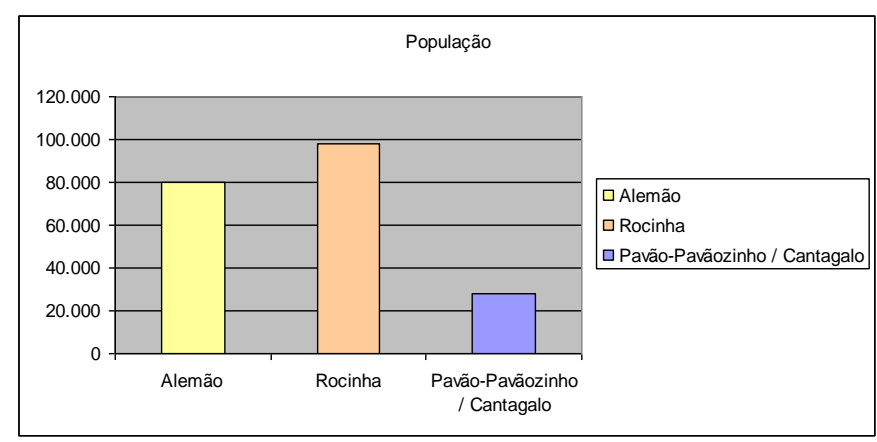

Fonte: Elaboração própria.

\section{Gráfico 2. Custo Intervenções PAC Favelas, 2011.}

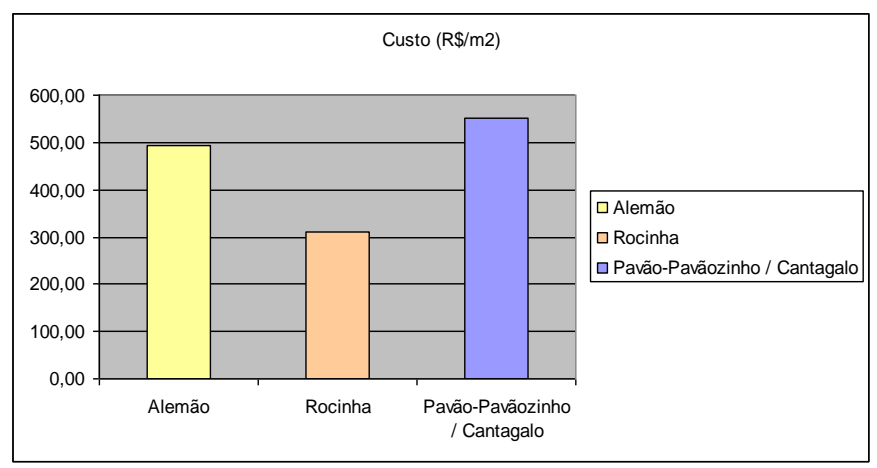

Fonte: Elaboração própria.

A articulação dos equipamentos e infraestruturas de mobilidade podem cumprir um papel importante na segurança pública, por exemplo - questão a ser considerada com atenção nas favelas cariocas. A possibilidade de deslocar-se facilmente para fins de lazer, trabalho, estudo, prática de exercícios etc - ou seja, a mobilidade urbana - está condicionada, entre outros fatores, pela segurança pública.

Sem a presença do Estado, esses assentamentos populares tornam-se territórios à mercê de organizações ou gangs para as quais o espaço tenha valor. Em geral, o valor atribuído é aquele vinculado ao comércio de drogas. Por certo, hoje, este negócio é um aspecto relevante, mas já não é mais o único, e talvez não seja o mais importante. Comércios clandestinos de serviços públicos, como o de transporte, o de comunicações e o de energia fazem parte do quotidiano desses assentamentos, cujo domínio adquire crescente valor.

O Complexo do Alemão foi ocupado pelas forças de pacificação do exército em $28 \mathrm{de}$ novembro de 2010 e as estações nos altos dos morros poderiam ser melhor aproveitadas, em consonância com a implantação de UPPs. O Pavão-Pavãozinho/Cantagalo teve sua UPP 
inaugurada em 23 de novembro de 2009, e às torres de elevadores, caso tivessem sido projetadas com outra visão, poderiam ser agregados outros programas. Em 20 de setembro de 2012 foi implementada na Rocinha a UPP, cujas forças policiais estiveram envolvidas com a injusta morte de um ajudante de pedreiro residente na comunidade. As UPPs demarcam um momento importante para a segurança pública não somente para as áreas com ausência de Estado, como também para toda a cidade. Contudo, devem ser vistas como o início de uma política, que ainda tem muito para avançar (Magalhães e Izaga, 2013).

Uma avaliação mais minuciosa das ações do PAC teria também que levar em conta os custos despendidos em cada favela. Se compararmos estas três favelas entre si, levando em consideração área e população, chegamos à conclusão de que os custos do PavãoPavãozinho/Cantagalo são os mais altos, os do Complexo do Alemão, intermediários e os da Rocinha, os mais baixos. Isto talvez indique a maior ênfase dada ao projeto e ao planejamento participativo na Rocinha, com um projeto construído comunitariamente. Isto não quer dizer que planejamentos participativos tenham custos mais baratos, mas sim que o planejamento criterioso pode sim deixar intervenções mais articuladas, que por esta razão serão também mais longevas.

Nas recentes manifestações de junho de 2013, cujo argumento inicial baseou-se no aumento de 20 centavos na tarifa dos transportes, para depois se transformar em um amplo movimento social por melhores serviços e contra a corrupção na estrutura política no Brasil, entre outros, os habitantes da Rocinha foram às ruas do Rio de Janeiro. Uma grande parte desses habitantes deixou claro que a favela tem outras prioridades e que o teleférico não lhes fazia falta, o que teve substancial apoio da sociedade e dos técnicos em geral. As manifestações retratam um momento de transformações na sociedade brasileira, no qual o urbano e o político interagem de maneira singular, e no qual a mobilidade urbana emerge, de certo, como ponto crítico.

Por fim, a midiatização do espaço da favela, e a sua exploração como parque temático através de vistosas intervenções, parecem também se apresentar de forma recorrente. Os tempos dos governantes são mais curtos que os tempos das cidades. Estejamos atentos e previdentes de critérios em relação ao que move essas ações.

\section{Referências Bibliográficas}

ABREU, Maurício de A. Evolução Urbana do Rio de Janeiro. Rio de Janeiro: IPLANRIOZahar, 1988. 
ANDREATTA, Verena. Cidades Quadradas, Paraísos Circulares: Os Planos Urbanísticos do Rio de Janeiro no Século XIX. Rio de Janeiro: Mauad, 2006.

ARQUITRAÇO ARQUITETURA.Vista da Rocinha a partir da passarela (Imagem). Rio de Janeiro: Arquitraço Arquitetura, 2013.

. Urbanização da Rua 4, Rocinha (Imagem). Rio de Janeiro: Arquitraço Arquitetura, 2013.

CÓDIGO DE OBRAS do Distrito Federal. Rio de Janeiro: Alaanak Laemmert, 1937.

CONDE, Luiz Paulo; MAGALHÃES, Sérgio. Favela-Bairro: uma outra história da cidade do Rio de Janeiro. Rio de Janeiro: Viver Cidades, 2004.

GOVERNO DO ESTADO DO RIO DE JANEIRO. Rocinha - Plano de Desenvolvimento Sustentável. Rio de Janeiro: Imprensa Oficial do Estado do Rio de Janeiro, 2012.

INSTITUTO BRASILEIRO DE GEOGRAFIA E ESTATISTICA - IBGE < http://www.ibge.gov.br/home/>.

MAGALHÃES, Sérgio; IZAGA, Fabiana. Close yet far. In: BURDETT, Ricky (org.). Urban Age City Transformations Conference Rio de Janeiro - 24/25 october 2013. Disponível em <rio2013.1secities.net/>.

MT ARQUITETURA. Plano Urbano da Rocinha (Imagem). Rio de Janeiro: MT Arquitetura, 2011.

QUADRO DO PAISAGISMO NO BRASIL - Quapá-Sel. Banco de imagens (Fotos 1, 2, 6, 7 e 12). Grupo de Pesquisa da USP, 2008.

SECRETARIA MUNICIPAL DE HABITAÇÃO. Plano de Desenvolvimento Urbanístico do Complexo do Morro do Alemão. Rio de Janeiro: Prefeitura do Rio, 2004.

VALLADARES, Licia. La favela d'un siècle à l'autre. Paris: Éditions de la Maison des sciences et de l'homme, 2006. 